\title{
MODUL BIOLOGI PADA MATERI KONSEP DASAR SEL MELALUI PEMBELAJARAN BIBLE BASED INTEGRATION UNTUK MENINGKATKAN HASIL BELAJAR BIOLOGI
}

\author{
Jerry Chrisny Marla Langi ${ }^{1)}$; Yusuf Bungkang ${ }^{2)}$; Johnson Siallagan ${ }^{3)}$ \\ ${ }^{1}$ SMA Kristen Kalam Kudus Jayapura; jerry03_jap@yahoo.com \\ ${ }^{2}$ Program Studi Magister Pendidikan IPA UNCEN ; bungkangyusuf@ gmail.com \\ ${ }^{3}$ Program Studi Magister Pendidikan IPA UNCEN; siallagan1968@ gmail.com
}

\begin{abstract}
The aim of the biology module is on cell basic concepts by using Bible-based integration to improve learning outcomes of students of Class XI IPA Kalam Kudus Christian Jayapura. The results of this study are: There is an increase in learning achievement of class XI students using the Bible Based Integration learning module with n-Gain RPP-1 0.61, n-Gain RPP-2 0.67, n-Gain RPP-3 0.74. The average $n$-Gain RPP is 0.67 with the medium category.
\end{abstract}

Keywords : Modules; Bible-based integration; basic cell concepts.

\begin{abstract}
ABSTRAK
Tujuan dari modul biologi adalah konsep dasar sel dengan menggunakan integrasi berbasis Alkitab untuk meningkatkan hasil belajar peserta didik Kelas XI IPA Kalam Kudus Kristen Jayapura. Hasil penelitian ini adalah: Ada peningkatan prestasi belajar siswa kelas XI menggunakan modul pembelajaran Integrasi Berbasis Alkitab dengan n-Gain RPP-1 0,61, n-Gain RPP-2 0,67, n-Gain RPP3 0,74. RPP n-Gain rata-rata adalah 0,67 dengan kategori sedang.
\end{abstract}

Kata Kunci : Modul; Integrasi Berbasis Alkitab; Konsep dasar sel.

\section{PENDAHULUAN}

Proses pembelajaran yang dilaksanakan pada sekolah Kristen adalah untuk melaksanakan Undang-Undang Nomor 20 tahun 2003 tentang Sistem Pendidikan Nasional, Pasal 3, yaitu mengembangkan potensi peserta didik agar menjadi manusia yang beriman dan bertakwa kepada Tuhan Yang Maha Esa, berakhlak mulia, sehat, berilmu, cakap, kreatif, mandiri, dan menjadi warga negara yang demokratis serta bertanggung jawab. Selain itu, dalam rangka menjalankan visi dan misi sekolah Kristen, setiap guru dan siswa harus memahami bagaimana worldview (pandangan) Alkitab tentang pengetahuan dan kehidupan manusia.

1) Allah adalah dasar dari semua realitas dunia ciptaan. Sebagai Pencipta, Allah adalah sumber dari segala sesuatu yang ada dalam rencana-Nya, Ibrani $1: 2$ - 3; 11:3 (LAI 2005).

2) Mazmur 139:13-16 (LAI 2005) menyatakan, "Sebab Engkaulah yang membentuk buah pinggangku, menenun aku dalam kandungan ibuku. Aku bersyukur kepada-Mu oleh karena kejadianku dahsyat dan ajaib; ajaib apa yang Kau buat, dan jiwaku benar-benar menyadarinya. 
Guru harus merancang dan menyiapkan materi pembelajaran agar dapat mengajar dengan baik. Yao Tung (2105: 160) mengatakan "Guru guru Kristen harus mempunyai kemampuan menggunakan referensi Alkitab untuk mengintegrasikan setiap subjek pembelajaran. Kegiatan kegiatan integrasi dalam proses pembelajaran harus melibatkan filsafat pendidikan Kristen , Christian Worldview dalam kerangka yang utuh (seperti pendekatan konsep Creation -
Fall-Redemption - Consummation).

\section{Tahapan BBI}

Smith dalam Yao Tung

(2015:161) mengkategorikan empat jenis tahapan dalam kurikulum berbasis Alkitab yaitu:

Tahapan 1 menyatakan Relegating the Bible, Tahapan 2 menyatakan Referencing the Bible, Tahapan 3 menyatakan Responding with the Bible dan Tahapan 4 menyatakan Rebuilding with the Bible

\section{Tabel 1 Mengeksplorasi Dasar Pandangan Hidup Kristiani untuk sebuah tema pembelajaran}

\begin{tabular}{|c|c|}
\hline $\begin{array}{l}\text { 4. Bagaimana kita dapat membantu siswa-siswi } \\
\text { untuk mengembangkan pemahaman yang lebih } \\
\text { dalam, pengalaman dan komitmen terhadap cara } \\
\text { hidup Kristen? Bagaimana kita memberi harapan } \\
\text { kepada mereka masa depan? } \\
\text { PEMENUHAN : Allah member Kita janjiNya }\end{array}$ & $\begin{array}{l}\text { Apakah maksud Allah untuk bidang realita } \\
\text { atau kebudayaan yang akan kita selidiki? } \\
\text { Apakah tujuan dan fungsinya? } \\
\text { PENCIPTAAN : Allah memberi kita mandat } \\
\text { Penciptaan }\end{array}$ \\
\hline $\begin{array}{l}\text { 3. Bagaimana Allah ingin } \\
\text { kita menanggapi? Bagaimana } \\
\text { jalan keluar dari masalah-masalah yang ada? } \\
\text { Bagaimana kegiatan manusia dapat bersifat } \\
\text { memulihkan? } \\
\text { PENEBUSAN : Allah memberikan kepada kita } \\
\text { Amanat Agung }\end{array}$ & $\begin{array}{l}\text { Apa yang telah terjadi? } \\
\text { Bagaimana manusia menyimpang dari } \\
\text { maksud Allah yang sebenarnya? } \\
\text { KEJATUHAN : Allah memberikan kepada } \\
\text { kita Perintah Agung }\end{array}$ \\
\hline
\end{tabular}

Modul salah satu bahan ajar yang digunakan dalam proses belajar mengajar untuk mempermudah peserta didik memahami pelajaran yang diberikan oleh guru. Bahan ajar dalam modul disusun oleh guru untuk membantu siswa dapat belajar secara mandiri sehingga dapat mengerti dan memahami tujuan pembelajaran. Modul menurut Daryanto (2013:31) dapat diartikan sebagai materi pelajaran yang disusun dan disajikan secara tertulis sedemikian rupa sehingga pembacanya dapat menyerap sendiri materi tersebut. Pengetahuan yang diberikan dalam pembelajaran setiap mata pelajaran dintegrasikan dengan Alkitab sebagai pedoman kegiatan pembelajaran.. Sel adalah kumpulan materi paling sederhana yang dapat hidup dan merupakan unit penyusun semua makhluk hidup. Melalui Alkitab kita bisa mendapatkan sejarah sebenarnya mengenai kehidupan manusia. (White 2005:84).

\section{METODE PENELITIAN}

Penelitian dan pengembangan Research and Development $(\mathrm{R} \& \mathrm{D})$ adalah rangkaian proses atau langkah-langkah dalam rangka mengembangkan suatu produk baru atau 
memperbaiki produk yang telah ada agar dapat dipertanggungjawabkan (Tegeh et.al, 2014.) Produk yang dihasilkan dapat berupa buku, modul, LKS, alat bantu pembelajaran di kelas atau di laboratorium. Dapat pula berupa perangkat lunak seperti program komputer untuk pengolahan data, aplikasi dan lainnya.

Model pengembangan yang dipilih dalam penelitian ini adalah model pengembangan ADDIE (Analyze, Design, Development, Implementation, Evaluation) yang dikembangkan oleh Robert Maribe Branch.

\section{Disain Uji Coba}

Uji coba dilakukan pada 5 peserta didik Kelas XII IPA ditunjukkan berdasarkan hasil ulangan harian biologi (Tabel 1)

Tabel 1. Desain Penelitian One Group Pretest Postest Design

\begin{tabular}{|c|c|c|}
\hline Pretest & Treatment & Postest \\
\hline $\mathrm{O}_{1}$ & $\mathrm{X}$ & $\mathrm{O}_{2}$ \\
\hline
\end{tabular}

Keterangan:

$\mathrm{O}_{1}$ menyatakan Kelas sebelum mengikuti pembelajaran dengan modul, $\mathrm{X}$ menyatakan Treatment pemberian Modul Biologi Pada Materi Konsep Dasar Sel Melalui Pembelajaran Bible Based Integration, dan $\mathrm{O}_{2}$ menyatakan kelas eksperimen setelah mengikuti pembelajaran dengan modul.

Uji coba dilakukan pada Kelas XI IPA SMA Kristen Kalam Kudus Jayapura dengan jumlah peserta didik 18 orang yang ditunjukkan berdasarkan hasil ulangan harian biologi.

\section{Teknik Analisa Data}

Data yang dipakai untuk melihat peningkatan hasil belajar adalah data hasil Pretest dan Postest. Data tersebut dianalisis untuk melihat skor hasil tes. Selanjutnya hasil tes tersebut dihitung rata-ratanya (mean), serta menghitung
n-Gain antara Pretest dan Postest. Untuk menghitung n-Gain dapat digunakan rumus Hake dalam Sugiyono (2015:74)., yaitu:

$$
\mathrm{n}-\text { Gain }=\frac{\mathrm{S}_{\text {post }}-\mathrm{S}_{\text {pre }}}{\mathrm{S}_{\text {maks }}-\mathrm{S}_{\text {pre }}}
$$

Keterangan:

$\mathrm{S}$ post menyatakan Skor posttest, $\mathrm{S}$ Pre menyatakan Skor Pretest, dan S maks menyatakan Skor Maksimum ideal Kriteria perolehan skor $\mathrm{n}$-Gain dapat dilihat pada tabel 2 berikut:

Tabel 2, Kategori perolehan skor n-Gain

\begin{tabular}{|c|c|}
\hline Batasan & Kategori \\
\hline $\mathrm{g}>0,7$ & Tinggi \\
\hline $0,3>\mathrm{g} \leq 0,7$ & Sedang \\
\hline $\mathrm{g} \leq 0,3$ & Rendah \\
\hline
\end{tabular}

Selanjutnya dilakukan pengolahan data prestest, posttest dan n-Gain dengan menggunakan Software statistical Package For Social Science (SPSS) versi 22.

Cara Pengembangan Modul Biologi Pada Materi Konsep Dasar Sel Melalui Pembelajaran Bible Based Integration Untuk Meningkatkan Hasil Belajar Peserta Didik Kelas XI IPA SMA Kristen Kalam Kudus Jayapura.

Penelitian ini menghasilkan produk pembelajaran berupa modul. Peneliti membuat pengembangan modul ini agar peserta didik lebih mudah untuk memahami "Materi konsep dasar sel melalui pembelajaran Bible Based Integration. Tahapan dalam pengembangan modul ini adalah sebagai berikut a) pengumpulan informasi; b) perencanaan; c) pengembangan produk; d) validasi; e ) ujicoba. 
Berikut tahapan secara rinci dari kegiatan tersebut. Kelayakan "Pengembangan Modul Biologi Pada Materi Konsep Dasar Sel Melalui Pembelajaran Bible Based Integration Untuk Meningkatkan Hasil Belajar Peserta Didik Kelas XI IPA SMA Kristen Kalam Kudus Jayapura

Kelayakan modul Biologi pada materi konsep dasar sel melalui pembelajaran $B B I$ ini dapat dilihat dari validasi validator materi, validator media, respon guru mata pelajaran dan peserta didik.

a. Validasi materi

Berdasarkan hasil validasi dari validator materi diperolehjumlah skor persentase validator 1 adalah $95,8 \%$, validator 2 adalah $93,8 \%$ sedangkan validator 3 adalah $89,6 \%$ rerata validasi adalah $93,1 \%$ dengan kategori modul layak.Ini menunjukan bahwa modul termasuk kategori sangat baikseperti ditunjukkan dalam gambar 1:

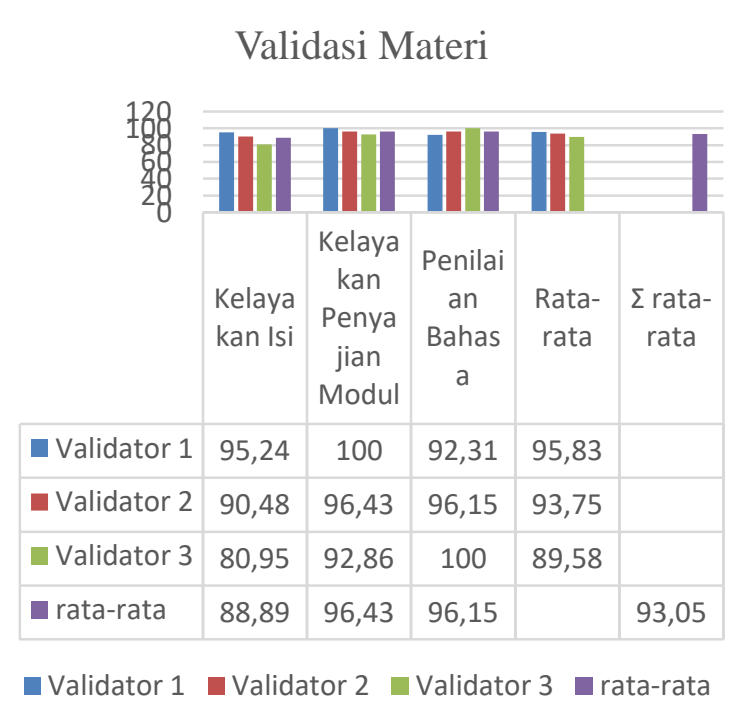

Gambar 1. Diagram batang validasi materi

b. Validasi media

Berdasarkan hasil validasi validator media diperoleh rerata sebesar 93,01\% dengan kategori sangat layak digunakan dalam pembelajaran seperti yang ditunjukkan dalam gambar 2

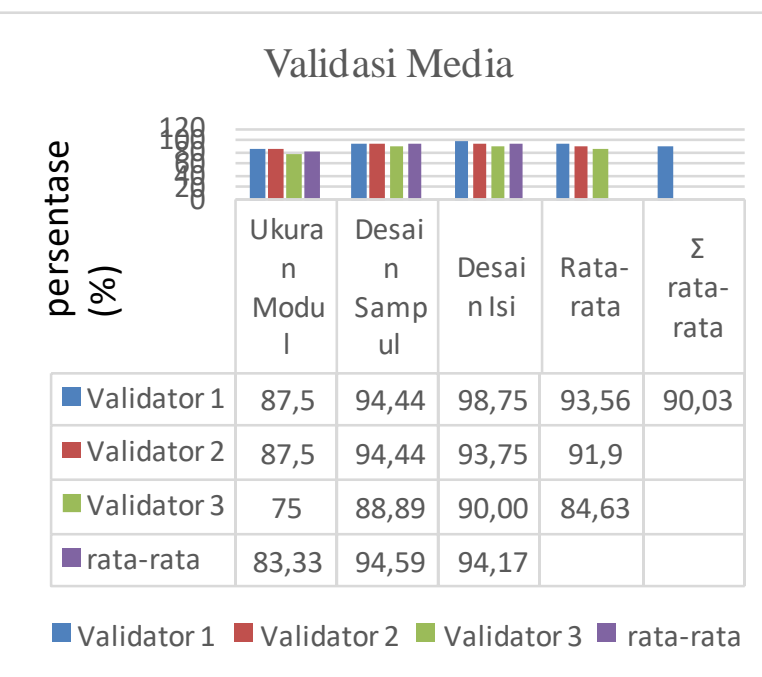

Gambar 2. Diagram batang validasi media

Berdasarkan gambar 2 diatas diperoleh persentase validator 1 adalah 96,77\%, validator 2 adalah 93,50\% sedangkan validator 3 adalah $88,71 \%$ dengan rerata hasil validasi adalah $93,01 \%$. Hasil ini menunjukkan bahwa modul dari segi media sangat layak digunakan dalam pembelajaran

c. Respon guru mata pelajaran

Berdasarkan angket yang diisi guru mata pelajaran biologi sebanyak 1 (satu) guru yang mengampu kelas XI IPA, memberikan respon $100 \%$ sangat setuju dengan adanya modul pembelajaran Materi Konsep Dasar Sel Melalui Pembelajaran BBI dapat menciptakan pembelajaran yang menyenangkan dan dapat mengenalkan kearifan lokal Papua. sehingga dapat diambil kesimpulan bahwa modul ini layak digunakan (gambar 3):

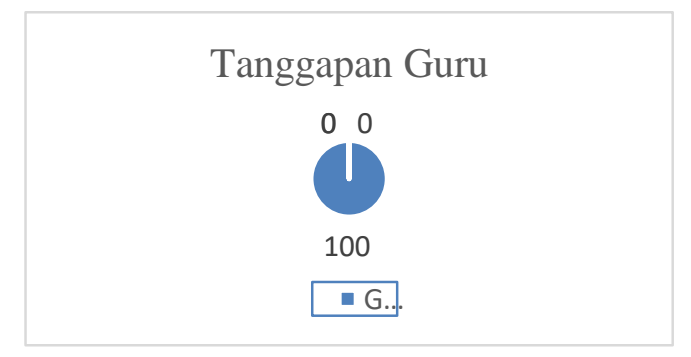

Gambar 3. Diagram lingkaran tanggapan guru 
a. Respon peserta didik

Hasil yang didapat dari pengisian angket respon peserta didik adalah dengan rerata persentase $89,06 \%$ dengan kategori layak, sehingga Materi Konsep Dasar Sel Melalui Pembelajaran Bible Based Integration layak digunakan dalam proses pembelajaran (gambar 4)

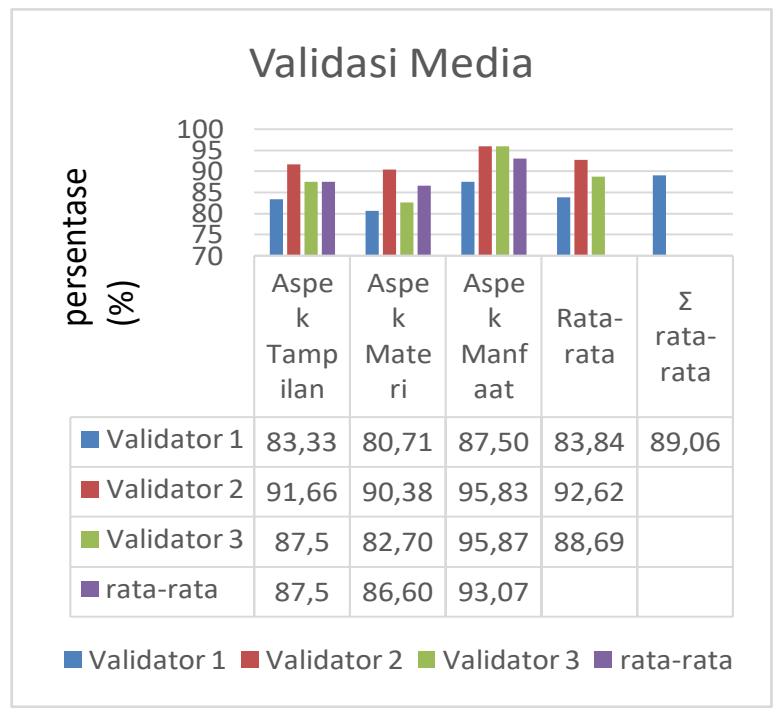

Gambar 4. Validasi media peserta didik

\section{HASIL DAN PEMBAHASAN}

Modul biologi melalui pembelajaran Bible Based Integrationpada materi konsep dasar sel dapat meningkatkan hasil belajar peserta didik diuji cobakan di SMA Kristen Kalam. Dari hasil uji n-Gain menunjukan adanya perbedaan peningkatan pada setiap pertemuan, dengan nilai n-Gain untuk RPP-1 adalah 0,61 ini menunjukan dapat meningkatkan prestasi belajar peserta didik, pada RPP-2 diperoleh n-Gain sebesar 0,67 dengan kategori sedang, berarti pembelajaran biologi dengan BBI dapat meningkatkan belajar peserta didik, pada RPP-3 diperoleh nGain sebesar 0,74 dengan kategori tinggi. Dari data tersebut rata-rata n-Gain adalah sebesar 0,67 yang termasuk dalam kategori sedang dan tingkat efektifitas cukup efektif seperti pada gambar 5

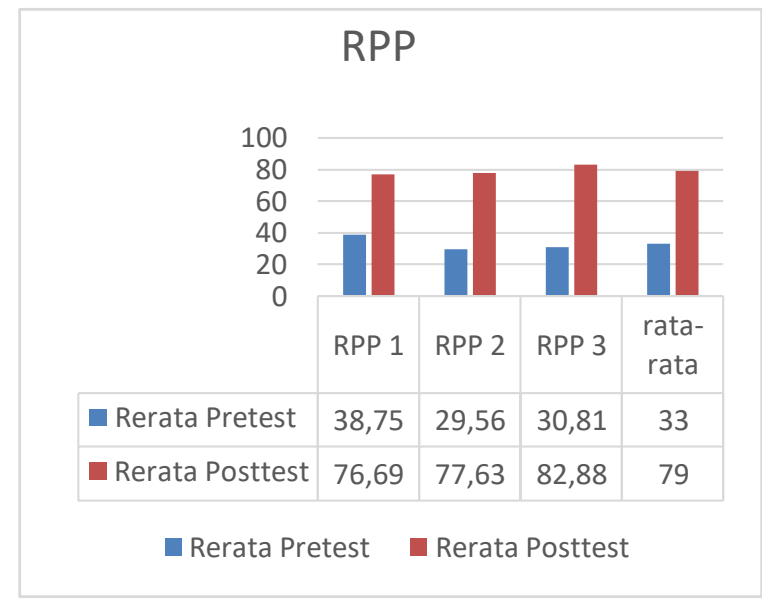

Gambar 5 Diagram batang hasil pembelajaran tiap RPP

Berdasarkan table 3 diatas, rata-rata nilai setiap pertemuan adalah 76,69 untuk RPP-1, 77,63 untuk RPP-2 dan 82,88 untuk RPP-3, sedangkan hasil pretestnya RPP-1 38,75, RPP-2 29,56, RPP-3 30,81, (rata-rata 33,00) setelah pembelajaran dengan modul, terjadi peningkatan sebesar 33,70 poin.

Tabel 3 Perolehan uji n-Gain rata-rata tiap pertemuan

\begin{tabular}{|c|c|c|c|c|c|}
\hline $\begin{array}{l}\text { Pertemuan } \\
\text { pada }\end{array}$ & $\begin{array}{c}\text { Katego } \\
\text { ri }\end{array}$ & $\underset{\mathrm{h}}{\text { Jumla }}$ & $\begin{array}{c}\text { Persentase } \\
(\%)\end{array}$ & $\begin{array}{c}\text { n-Gain } \\
\text { rata-rata }\end{array}$ & Kategori \\
\hline \multirow{3}{*}{ RPP-1 } & Rendah & 4 & 25 & \multirow{3}{*}{0,61} & \multirow{3}{*}{ Sedang } \\
\hline & Sedang & 4 & 25 & & \\
\hline & Tinggi & 8 & 50 & & \\
\hline \multirow{3}{*}{ RPP-2 } & Rendah & 6 & 37,5 & \multirow{3}{*}{0,67} & \multirow{3}{*}{ Sedang } \\
\hline & Sedang & 2 & 12,5 & & \\
\hline & Tinggi & 8 & 50 & & \\
\hline \multirow{3}{*}{ RPP-3 } & Rendah & 4 & 25 & \multirow{3}{*}{0,74} & \multirow{3}{*}{ Tinggi } \\
\hline & Sedang & 2 & 12,5 & & \\
\hline & Tinggi & 10 & 62,75 & & \\
\hline Rata-rata & & & & 0,67 & Sedang \\
\hline
\end{tabular}

Berdasarkan tabel 3 hasil uji n-Gain diperoleh rata-rata sebesar 0,67 dalam kategori sedang, hal ini sesuai dengan pendapat Ali dalam Valent (2015) pembelajaran biologi 
dengan modul mampu meningkatkan hasil belajar kognitif peserta didik dengan kriteria sedang. Kelebihan modul biologi pada materi konsep dasar sel melalui pembelajaran Bible Based Integration peserta didik kelas XI IPA SMA Kristen Kalam Kudus Jayapura. Pemebelajaran Bible Based Integration ini sejalan dengan Harro Van Brummelen, (2011) bahwa pemelajaran harus dilaksanakan berlandaskan ajaran Kristus.

Modul biologi pada materi konsep dasar sel melalui pembelajaran Bible Based Integration ini memiliki kelebihan :

1) Modul ini adalah wujud implementasi visi dan misi Sekolah Kristen Kalam Kudus Indonesia Cabang Jayapura

2) Modul pertama di SMA Kristen Kalam Kudus Jayapura yang menggunakan Bible Based Integration.

Respon peserta didik dengan rata-rata 83,33\% pembelajaran BBI dapat meningkatkan pemahaman materi konsep dasar sel.

Kekurangan dari modul pembelajaran Bible Based Integration adalah sebagai berikut:

1) Perlu pembahasan lebih mendalam khususnya konsep - konsep Alkitab dalam pembelajaran biologi.

2) Materi dangambar yang diajarkan harus dikaitkan dengan Alkitab

\section{SIMPULAN DAN SARAN}

\section{SIMPULAN}

Simpulan dalam penelitian ini adalah terdapat peningkatan prestasi belajar peserta didik kelas dengan n-Gain RPP-1 sebesar 0,61, nGain RPP-2 sebesar 0,67, n-Gain RPP-3 sebesar 0,74. Rerata n-Gain RPP adalah 0,67 dengan kategori sedang.

\section{SARAN}

Agar pada materi konsep dasar sel dapat digunakan pembelajaran melalui buble based integration untuk meningkatkan hasil belajar biologi.

\section{DAFTAR PUSTAKA}

Daryanto, 2013, Media Pembelajaran. Penerbit Gava media Yokyakarta

Ellen G. White, 2005. Dasar - Dasar Pendidikan., Indonesia Publishing House

Harro Van Brummelen, 2011. Berjalan Bersama Tuhan di kelas. Pendekatan Belajar Mengajar Secara Kristiani. Penerbit ACSI.

I Made Tegeh, I Nyoman, 2014, Penelitian dan Pengembangan. Penerbit Graha Ilmu

Khoe Yao Tung, 2015. Menuju Sekolah Kristen Impian Masa Kini. Isu-isu Filsafat, Kurikulum, Strategi dalam Pelayanan Sekolah Kristen. Penerbit Andi.

Lembaga Alkitab Indonesia, 2005. ALKITAB

Sugiyono. 2015. Petode Penelitian dan Pengembangan. Research and Development. Penerbit. Alfabeta, CV.

Valent Sari Danisa, Suciati, Widha Sunarno (2015) "Pengembangan Modul Berbasis Brain Based Learning Disertai Vee Diagram Untuk Meningkatkan Hasil Belajar Ranah Kognitf 